\title{
Full-term low birth weight and its relationship with the socioeconomic conditions of municipalities in Antioquia: Spatio-temporal analysis
}

\author{
Luz Stella Álvarez-Castaño ${ }^{\text {, Beatriz Caicedo-Velásquez², Catalina Castaño-Díez³ }}$, \\ Marc Marí-Dell'Olmo ${ }^{4,5,6,7}$, Mercè Gotsens ${ }^{4,5,6,7}$ \\ 1 Grupo de Investigación en Determinantes Sociales de la Salud y la Nutrición, Universidad de Antioquia, \\ 2 Grupo de Investigación en Epidemiología, Universidad de Antioquia, Medellín, Colombia \\ 4 Agència de Salut Pública de Barcelona, Barcelona, España \\ 5 CIBER Epidemiología y Salud Pública (CIBERESP), Madrid, España \\ 6 Institut d'Investigació Biomèdica, IIB Sant Pau, Barcelona, España \\ 7 Universitat Pompeu Fabra, Barcelona, España
} Medellín, Colombia

3 Nutrición y Dietética, Medellín, Colombia

Introduction: Low birth weight is one of the main health predictors for childhood and adulthood. It is highly prevalent in developing countries and in children from poorer social classes.

Objective: To analyze the geographical distribution and the trends of full-term low birth weight in the 125 municipalities of the department of Antioquia and their association with the socioeconomic conditions of the municipalities between 2000 and 2014.

Materials and methods: We conducted a longitudinal ecological study. The dependent variable was the prevalence of full-term low birth weight in 125 municipalities. The socioeconomic conditions of the municipalities were evaluated using the Human Development Index and the unsatisfied basic needs index. Results: Between 2000 and 2014, the prevalence of full-term low birth weight in Antioquia was 2.7 per 100 live births; this prevalence decreased steadily over time. This trend was also observed between regions, with the exception of the Occidente and Urabá regions, which showed increases of approximately $20.0 \%$. The results also showed a reduction in geographical differences between the 125 municipalities, with the coefficient of variation decreasing from $20.6 \%$ to $13.72 \%$ over the 14 -year period. Finally, we found a positive social gradient between the full-term low birth weight prevalence and the level of development in the municipalities.

Conclusion: Full-term low birth weight prevalence decreased between 2000 and 2014, with some regions showing greater reductions than others. Paradoxically, less developed and poorer areas had a lower prevalence, which may be a result of underreporting of birth weight information in these municipalities.

Key words: Health inequalities; spatial analysis, geographical mapping, social determinants of health. doi: https://doi.org/10.7705/biomedica.v38i3.3734

Bajo peso al nacer en niños nacidos a término en Antioquia y su relación con las condiciones socioeconómicas de los municipios, un análisis espacio-temporal

Introducción. El bajo peso al nacer es uno de los principales indicadores predictores de la salud en la infancia y la adultez, y su prevalencia es elevada en los países en desarrollo y en niños de clases sociales pobres.

Objetivo. Analizar la distribución geográfica y la tendencia del bajo peso al nacer de niños nacidos a término en los 125 municipios de Antioquia, y su asociación con las condiciones socioeconómicas de los municipios entre el 2000 y el 2014.

Materiales y métodos. Se hizo un estudio ecológico longitudinal. La variable dependiente fue el bajo peso al nacer a término en los 125 municipios; las condiciones socioeconómicas de los municipios se evaluaron según sus índices de desarrollo humano y de necesidades básicas insatisfechas.

\footnotetext{
Authors' contributions:

Luz Stella Álvarez-Castaño: main idea of the study, development work, writing and interpretation of the findings

Beatriz Caicedo-Velásquez: statistical design, data analysis, interpretation of findings

Catalina Castaño-Díez: data analysis and interpretation of the findings

Marc Marí-Dell'Olmo and Mercè Gotsens: data processing and analysis

All the authors reviewed and approved the final version of this manuscript.
} 
Resultados. La prevalencia de bajo peso al nacer a término en Antioquia fue de 2,7 por 100 nacidos vivos entre 2000 y 2014, con una reducción constante. Esta tendencia se observó en todas las subregiones, excepto en las de Occidente y Urabá, en las cuales el incremento fue de 20 \%. Los resultados evidenciaron una reducción de las brechas geográficas entre los 125 municipios. Además, en todos los trienios se evidenció un gradiente social positivo en la asociación entre el bajo peso al nacer a término y las condiciones socioeconómicas de los municipios.

Conclusión. Se observó una mayor tendencia decreciente del bajo peso al nacer a término en unas subregiones. Paradójicamente, se registró una menor prevalencia de bajo peso al nacer a término en las regiones menos desarrolladas y más pobres, lo que posiblemente se explica por el subregistro del peso al nacer.

Palabras clave: desigualdades en la salud; análisis espacial, mapeo geográfico, determinantes sociales de la salud.

doi: https://doi.org/10.7705/biomedica.v38i3.3734

Currently, low birth weight (LBW) is listed as the most important predictive index of child mortality (especially neonatal mortality) and the calculation of its prevalence is considered a relevant health indicator (1). Low birth weight is defined by the World Health Organization (WHO) as a newborn with a birth weight of 2,500 grams or less (2). The United Nations, the United Nations International Children's Emergency Fund (UNICEF), and the Economic Commission for Latin American and the Caribbean (ECLAC) have reported that the risk of neonatal death in children born with a LBW is four times higher than that of children weighing 2,500 to 2,999 $\mathrm{g}$ at birth and 10 to14 times higher compared to children born with weights between 3,000 and $3,499 \mathrm{~g}(3)$.

Low birth weight is an important prediction mechanism for newborn health and survival. It is a determinant of nutritional status and is associated with morbidity, decreased immune functions and difficulties in cognitive development. In adulthood, LBW is associated with increased risk of developing non-communicable diseases (4). It is estimated that a significant number of children who survive LBW suffer from neurological and intellectual disorders. Moreover, high LBW prevalence increases outpatient and hospital morbidities for different diseases, such as acute respiratory infection, acute diarrheal disease, urinary sepsis and anemia(5).

Two indicators are used by governmental health institutions in Colombia for birth weight surveillance: LBW in all gestational ages and full-term LBW, which excludes preterm babies (5).

\footnotetext{
Corresponding author:

Luz Stella Álvarez-Castaño, Carrera 75 № 65-87, bloque 44, oficina 112, Universidad de Antioquia, Medellín, Colombia Telephone number: (574) 2199217

luz.alvarez@udea.edu.co

Received: 05/01/17; accepted: 15/12/17
}

According to the Pan American Health Organization (PAHO), in 2012, Colombia had a LBW prevalence of $9,2 \%$, a rate that exceeds the average for Latin America and the Caribbean (7,8\%) (5). A study carried out by the Instituto Nacional de Salud found that in Colombia, the prevalence of LBW rose continuously from $7.2 \%$ in 1998 to $8.6 \%$ in 2012 . Although there are still no definitive data, the rate for 2015 was estimated to be $9.0 \%$, assuming that conditions remained the same. The cited study also showed that Antioquia's full-term LBW prevalence was $3,0 \%$ in 2015 , which was higher than the Colombian average of $2.6 \%$ (5). Antioquia is located in northwestern Colombia and is the most populous department in the country, and the sixth in extension (6).

Low birth weight has contextual and individual determinants, including the following: Being the firstborn, gender (more frequent in girls), having complications in the womb due to non-specific infections, and being a child of a young mother or a mother living in precarious socioeconomic conditions who has poor nutrition for long durations before and during pregnancy $(1,4,7)$. Other factors that influence LBW are prior medical risks (i.e., arterial hypertension and kidney or thyroid disease) and complications during pregnancy, including gestational hypertension, inadequate weight gain during pregnancy, a short interval between pregnancies, gestational diabetes and performing an excessive or inappropriate amount of physical work $(1,8)$.

Low birth weight is a phenomenon that mainly occurs in developing countries, where it is one of the main mechanisms for the intergenerational transmission of poverty and inequality (9). In industrialized countries, the percentage of LBW is approximately $7 \%$, whereas, in developing countries, it is higher than $17 \%$ (7) and can exceed $40 \%$ in some cases (4). 
The effects of the geographical location on birth weight have been observed for various features at the individual level (10). Contextual and multi-level analysis studies have attempted to explain the association between the individual and the territory or geographical area and LBW $(11,12)$. Some studies have reported that neighborhood conditions influence the health outcomes of children, with impoverished environments, low education levels, and overcrowded housing all being associated with an increased risk of LBW (13-15). Furthermore, it has been suggested that other aspects of the physical and social environment are related to LBW. These factors include stress, environments with violence and crime, racial discrimination, air pollution, low levels of social cohesion, environments with few opportunities for outdoor recreation, and unemployment $(11,15-17)$.

In this study, we aimed at determining the geographical distribution and the trends in low birth weight in the municipalities of the department of Antioquia and their association with the socioeconomic conditions of the municipalities between 2000 and 2014 .

\section{Materials and methods}

\section{Design, unit of analysis and study population}

We conducted an ecological study that analyzed full-term LBW trends using data from the 125 municipalities of Antioquia between 2000 and 2014. Antioquia is divided geographically into 9 subregions: Bajo Cauca, Magdalena Medio, Nordeste, Norte, Occidente, Oriente, Suroeste, Urabá and Valle de Aburrá. The analysis units were the 125 municipalities, which contain $14,5 \%$ of the Colombian population (18). In 2012, the smallest municipality had a population of 2,290 inhabitants and the largest had a population of 2,393,011 inhabitants. The study population consists of live births to mothers who resided in any of the 125 municipalities of Antioquia between 2000 and 2014.

The subregions with a better quality of life include Valle de Aburrá, Oriente, and Suroeste. Medellín and other larger cities are all located in the first subregion. Manufacturing and services are the leading economic sectors in this subregion. The Oriente and Suroeste subregions have mediumsized cities, and their economies are based on agricultural production, including coffee, and services (6).

The poorest regions of Antioquia are Urabá and Bajo Cauca. Urabá's economy is based on the banana agroindustry, while Bajo Cauca is a mining region. Both are characterized by the presence of illegally armed groups and have a strong presence of illicit crops and illegal mining (6).

The Norte, Nordeste, Occidente and Magdalena Medio subregions have small cities with high proportions of poor populations working on small farms who lack basic public utilities. All of the subregions have armed illegal groups (6).

\section{Information sources}

Data on live births grouped by municipality and year (2000-2014) were obtained from the Departamento Administrativo Nacional de Estadísticas, (DANE). The data on municipal socioeconomic characteristics for 2005 were obtained from the Statistical Yearbook of Antioquia and the National Human Development Report.

\section{Variables}

Dependent variable: Prevalence of $L B W$ at the municipal level. The dependent variable was the LBW, which was defined as the number of live births with a birth weight of 2,500 grams or less in every 100 live births from singleton pregnancies lasting 37 weeks of gestation, or more. Therefore, hereafter, we call our dependent variable Full-Term Low Birth Weight (FT-LBW). The mothers in this study were between 18 and 45 years of age.

Independent variables: Socioeconomic conditions of the municipalities. We analyzed two socioeconomic indicators as independent variables:

- The percentage of the population with unsatisfied basic needs (UBN) to measure the proportion of the population that had at least one of the following unmet basic needs in 2005: inadequate housing, housing with critical overcrowding, housing with inadequate services, housing with high economic dependence, and housing with school-age children who did not attend school. This variable was expressed in quintiles.

- The municipal human development index (HDI) to measure the level of development in each municipality in 2005 for three dimensions: health, education, and income. This variable was expressed in quintiles.

\section{Statistical analysis}

To provide a sample size adequate to produce robust LBW estimates, birth data were aggregated into five time-periods: 2000-2002, 2003-2005, 2006-2008, 2009-2011, and 2012-2014. 
First, we estimated the prevalence of FT-LBW for each subregion, municipality and period using as the numerator, the number of live births to mothers between ages 18 and 45 who delivered babies with a birth weight of 2.500 grams or less at 37 or more weeks of gestation. The denominator was the total number of live births resulting from singleton pregnancies lasting 37 weeks of gestation or more in mothers between 18 and 45 years of age. Then we multiplied this ratio by 100 to obtain the prevalence of FT-LBW.

To improve the accuracy of the estimates for municipalities with a low number of live births, the prevalence for each time period was smoothed using the Bayesian hierarchical model proposed by Besag, York, and Mollie (BYM) $(19,20)$. This model combines information on LBW from each municipality with the average of the neighboring municipalities, thereby reducing the variability of the estimates. The BYM model was specified for each municipality and study period as:

$$
\begin{aligned}
& Y_{i} \sim \operatorname{Binomial}\left(n_{i}, p_{i}\right) \\
& \text { logit }\left(p_{i}\right)=B_{0}+v_{i}+u_{i}
\end{aligned}
$$

where $n_{i}$ is the denominator within each municipality $i$. Prevalence in each municipality $i$ is represented by $p_{i}$. The model has two random effects reflecting the non-spatial and spatial variables $\left(v_{i}\right.$, and $u_{i}$ respectively). These random effects allow for the estimation of the smoothed prevalence for each municipality and time period as $\exp \left(\beta_{0}+v_{i}+u_{i}\right)$. For spatial effects, a priori distributions were assigned through an intrinsic conditional auto-regression (ICAR) distribution with a variance of $\sigma_{v}^{2}(20)$. For non-spatial effects, a normal distribution was used with a mean of zero and a variance of $\sigma_{u}^{2}$. A halfnormal distribution with a mean of 0 and a precision of 0.0001 was assigned to the standard deviations $\sigma_{v}$ and $\sigma_{u}(21)$. A normal vague prior distribution was assigned to the parameters $\propto$.

This model estimates the a posteriori mean of the smoothed prevalence and its respective 95\% credible interval for each municipality. Maps and tables are used to represent the distribution of the smoothed prevalence values and the probability of each municipality showing an FT-LBW prevalence higher than that of Antioquia as a whole (i.e., for each municipality $I$ was calculated as $\operatorname{PrP}_{i}=$ Probability (smoothedP $\mathrm{P}_{\mathrm{i}}>$ prevalence of Antioquia).

Descriptive statistics analyses were conducted using: 1) Tables and bar graphs displaying the prevalence of each period and subregion and its respective $95 \%$ confidence intervals; 2 ) choropleth maps displaying the geographical variation of the FT-LBW prevalence in each period and its corresponding a posteriori mean; 3) contingency tables showing the distribution of FT-LBW prevalence according to period and quintiles of the socioeconomic variables, and 4) estimates of the coefficient of variation for each period, which help to describe the geographical inequalities of FTLBW and their evolution over time. The coefficient of variation was calculated using the ratio between the standard deviation of the municipal prevalence values and their mean.

Finally, we analyzed the evaluation of the relationship between the FT-LBW prevalence and the socioeconomic conditions in the five periods, as well as their changes over time. For this analysis, the BYM model was used as an ecological regression model that included socioeconomic variables separately, the time period and its interaction with socioeconomic variables. These were categorized into quintiles and were included in separate models as four dummy variables (QSE), with the less poor or less developed areas serving as the reference group. Similarly, time period was included in the model using four dummy variables $(P)$, in which the first period (2000-2002) was used as the reference category. The ecological regression model was specified as follows:

$$
\begin{aligned}
& \operatorname{logit}\left(p_{i t}\right)=\beta_{0}+\sum_{j=1}^{4} \beta_{j} \mathrm{P}_{(\mathrm{j}+1), \mathrm{t}}+\sum_{j=5}^{8} \beta_{j} \mathrm{Q} \cdot \mathrm{SE}_{(\mathrm{j}-3), \mathrm{i}}+\sum_{j=9}^{12} \beta_{\mathrm{j}} \cdot \mathrm{P}_{2, \mathrm{t}} \cdot \mathrm{QSE}_{(\mathrm{j}-7), \mathrm{i}} \\
&+\sum_{j=13}^{16} \beta_{j} \cdot \mathrm{P}_{3, \mathrm{t}} \cdot \mathrm{QSE}(\mathrm{j}-11), \mathrm{i} \\
&+\sum_{j=17}^{20} \beta_{\mathrm{j}} \cdot \mathrm{P}_{4, \mathrm{t}} \cdot \mathrm{QSE}_{(\mathrm{j}-15), \mathrm{i}} \\
&+\sum_{j=21}^{24} \beta_{\mathrm{j}} \cdot \mathrm{P}_{5, \mathrm{t}} \cdot \mathrm{QSE}_{(\mathrm{j}-19), \mathrm{i}}+v_{i t}+u_{i t}
\end{aligned}
$$

where each municipality is represented as $i$ and each period as $t(\mathrm{t}=1$ for period 2000-2002, $\mathrm{t}=2$ for period 2003-2005, $\mathrm{t}=3$ for period 2006-2008, $\mathrm{t}=4$ for period $2009-2011$, and $\mathrm{t}=5$ for period 2012 2014). Table 1 shows the main results of this model. Specifically, for each period, the relative risk (RR) of FT-LBW in each socioeconomic group, along with the corresponding $95 \%$ credible intervals $(95 \% \mathrm{Cl})$. That is, for the first period, $\exp \left[\beta_{\mathrm{j}}\right](j=5, \ldots, 8)$, for the second period, $\exp \left[\beta_{\mathrm{j}}+\beta_{\mathrm{j}+4}\right](j=9, \ldots, 12)$, for the third period, $\exp \left[\beta_{j}+\beta_{j+8}\right](j=13, \ldots, 16)$, for the fourth period, $\exp \left[\beta_{j}+\beta_{j+12}\right](j=17, \ldots, 20)$, and for the fifth period, $\exp \left[\beta_{j}+\beta_{j+16}\right](j=21 \ldots, 24)$.

These models were estimated using the integrated nested Laplace approximation (INLA) algorithms available in the INLA library of the R.3.3.0 statistical package (22). 


\section{Results}

Between 2000 and 2014, there were 886,570 live births in Antioquia. Of these, 24,312 were born with FT-LBW, for an estimated prevalence of 2.7 per 100 live births. Analysis of the differences in FT-LBW between subregions found that three subregions had a significantly higher FT-LBW prevalence than Antioquia as a whole (Norte, Oriente, and Valle de Aburrá). The prevalence in the Norte subregion was substantially greater than the prevalence in Antioquia, whereas the prevalence estimates for Bajo Cauca, Magdalena Medio, Nordeste, and Urabá were lower (figure 1).

When we examined FT-LBW trends, it was clear that there was a significant $34 \%$ decrease in its prevalence from the first time period (2000-2002) to the fifth (2012-2014), as the rate changed from 3.21 births/100 to $2.12 / 100$ (table 2).
This decreasing trend was similar between subregions. Figure 2 shows the proportion of the change in the prevalence for each subsequent time period compared to the first time period (2000-2002). Positive values indicate a reduction, whereas negative ones indicate increases. The figure shows how the largest reductions in all measured time periods were observed in Nordeste, Valle de Aburrá, and Bajo Cauca subregions, with $43,5 \%, 36,5 \%$, and $34,0 \%$ decreases, respectively, compared with the first time period. In contrast, the Occidente and Urabá subregions had increased prevalence rates of approximately $20.0 \%$ for the 2006-2008 and 20092011 periods, compared with the first time period. The three subregions with the largest improvement in the last time period were Occidente, Urabá, and Norte. These subregions initially had increasing prevalence rates in 2006 and 2011 but reversed this trend with marked reductions in 2012-2014.

Table 1. Relative risk of full-term low birth weight in quintiles of poverty (UBN) and development (HDI) by time period in 125 municipalities in Antioquia, 2000-2014

\begin{tabular}{|c|c|c|c|c|c|}
\hline & $2000-2002$ & 2003-2005 & 2006-2008 & 2009-2011 & 2012-2014 \\
\hline & $\operatorname{RR}(95 \% \mathrm{Cl})$ & RR $(95 \% \mathrm{Cl})$ & $\operatorname{RR}(95 \% \mathrm{Cl})$ & $\operatorname{RR}(95 \% \mathrm{Cl})$ & $\operatorname{RR}(95 \% \mathrm{Cl})$ \\
\hline \multicolumn{6}{|l|}{ UBN } \\
\hline Less poor & 1.00 & 1.00 & 1.00 & 1.00 & 1.00 \\
\hline Q2 & $0.92(0.76-1.09)$ & $0.92(0.74-1.13)$ & $0.98(0.77-1.23)$ & $1.23(0.97-1.54)$ & $1.05(0.84-1.29)$ \\
\hline Q3 & $0.88(0.73-1.05)$ & $0.94(0.76-1.15)$ & $1.08(0.86-1.35)$ & $1.04(0.82-1.30)$ & $1.14(0.92-1.40)$ \\
\hline Q4 & $0.80(0.65-0.98)$ & $0.8(0.62-1.00)$ & $0.89(0.69-1.15)$ & $0.94(0.72-1.21)$ & $0.83(0.65-1.04)$ \\
\hline Poorest & $0.85(0.67-1.06)$ & $0.81(0.61-1.04)$ & $0.94(0.71-1.24)$ & $0.99(0.74-1.31)$ & $0.89(0.70-1.13)$ \\
\hline \multicolumn{6}{|l|}{ HDI } \\
\hline Less developed & 1.00 & 1.00 & 1.00 & 1.00 & 1.00 \\
\hline Q2 & $1.12(0.92-1.36)$ & $0.93(0.75-1.14)$ & $0.98(0.77-1.23)$ & $0.93(0.74-1.16)$ & $1.02(0.80-1.27)$ \\
\hline Q3 & $1.08(0.87-1.31)$ & $1.11(0.89-1.37)$ & $1.18(0.93-1.49)$ & $1.09(0.86-1.36)$ & $1.17(0.92-1.46)$ \\
\hline Q4 & $1.17(0.94-1.44)$ & $1.19(0.94-1.49)$ & $1.15(0.89-1.46)$ & $1.36(1.06-1.72)$ & $1.38(1.07-1.73)$ \\
\hline More developed & $1.05(0.83-1.31)$ & $0.98(0.76-1.25)$ & $0.96(0.73-1.24)$ & $1.13(0.87-1.45)$ & $1.11(0.86-1.41)$ \\
\hline
\end{tabular}

Q2: quintile 2; Q3, quintile 3; Q4: quintile 4; Cl: confidence interval

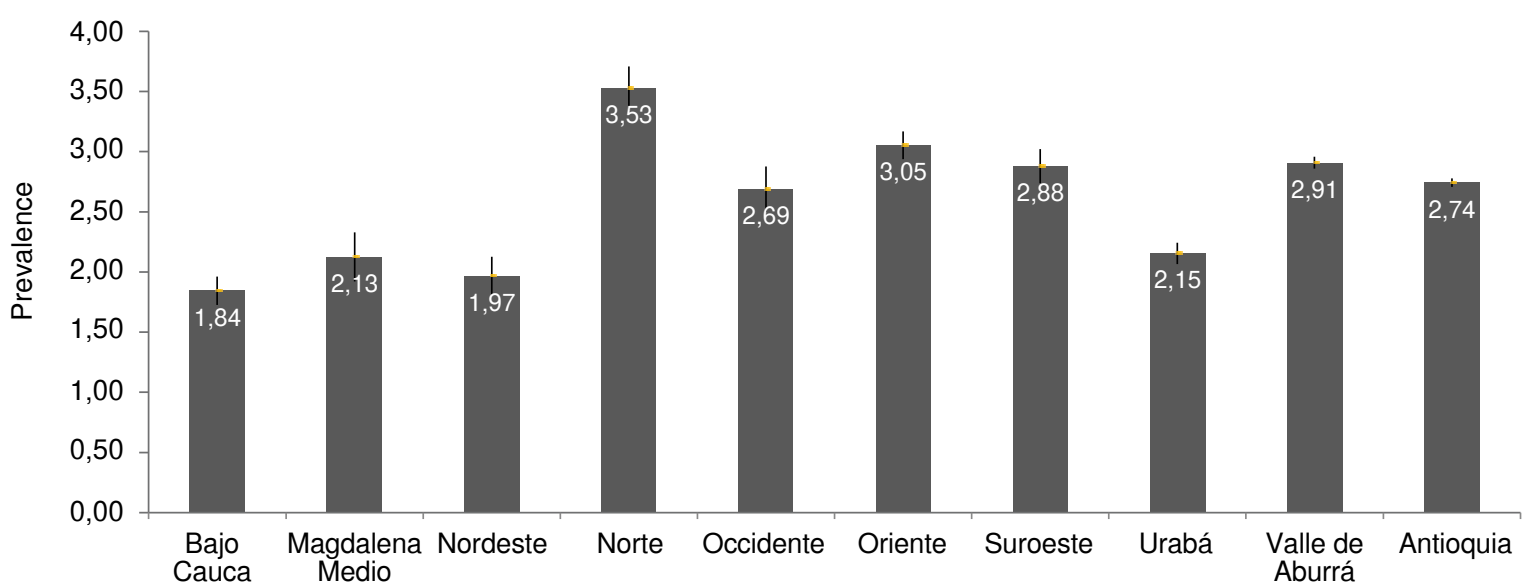

Figure 1. Prevalence and respective $95 \%$ confidence intervals of full-term low birth weight by subregion in Antioquia, 2000-2014 
Table 2. Distribution of live births and prevalence (percent) of full-term low birth weight, Antioquia, 2000-2014

\begin{tabular}{ccccc}
\hline Period & Full-term low birth weight $(\mathbf{n})$ & Births $\mathbf{( n )}$ & Prevalence & IC $(\mathbf{9 5 \% )}$ \\
\hline $2000-2002$ & 6,472 & 201,862 & 3.21 & $3.12-3.28$ \\
$2003-2005$ & 5,272 & 187,330 & 2.81 & $2.73-2.89$ \\
$2006-2008$ & 5,152 & 183,982 & 2.80 & $2.72-2.87$ \\
$2009-2011$ & 4,137 & 158,477 & 2.61 & $2.53-2.69$ \\
$2012-2014$ & 3,279 & 154,919 & 2.12 & $2.04-2.18$ \\
$2000-2014$ & 24312 & 886,570 & 2.74 & $2.70-2.77$ \\
\hline
\end{tabular}

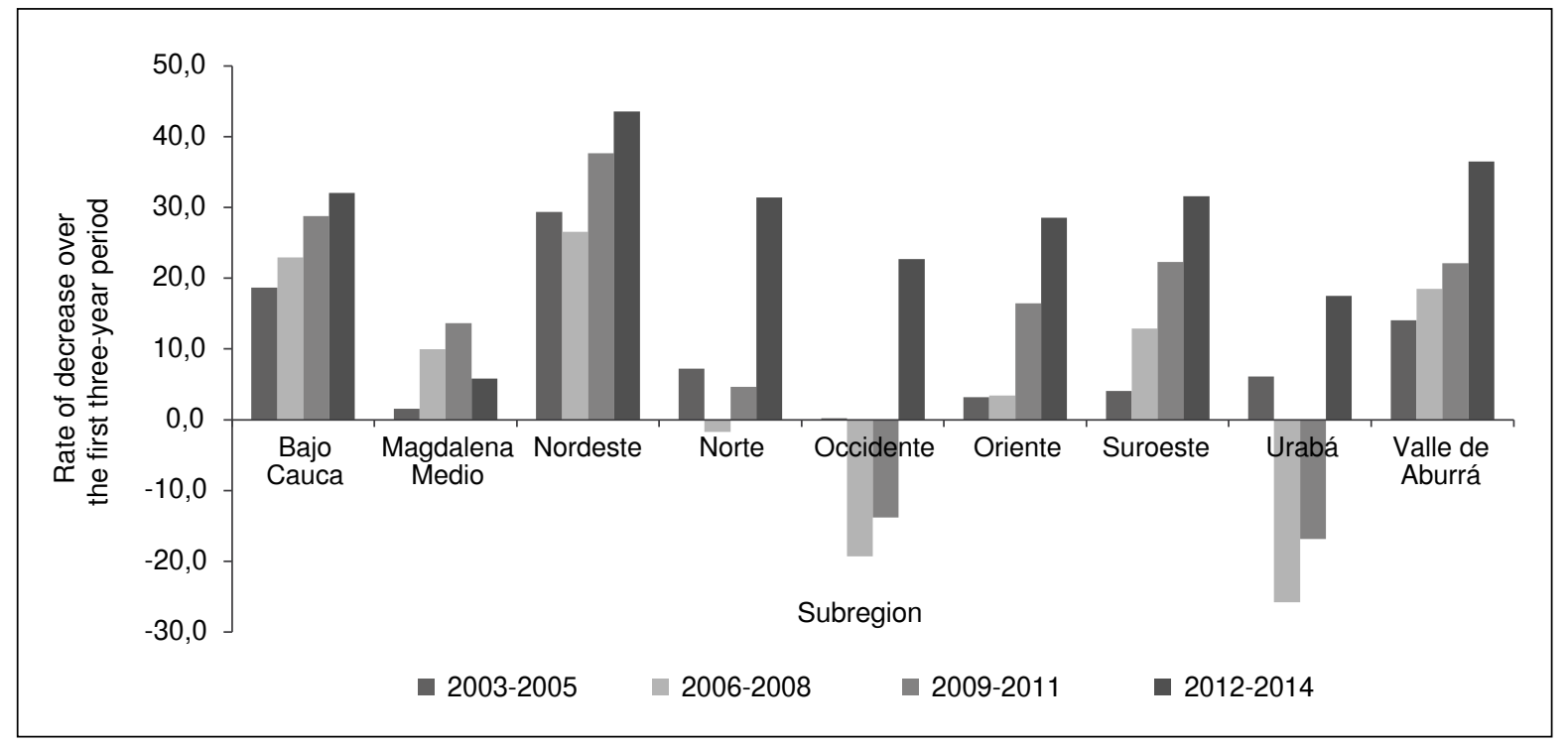

Figure 2. Change in the prevalence of full-term low birth weight comparing the first period (2000-2002) with the other study periods, Antioquia

The trends observed in Antioquia as a whole and in each subregion did not provide information on the larger geographical variations in FT-LBW. The spatial patterns of the smoothed prevalence values and the respective posterior probabilities (PPR) are shown in figure 3 . The results for the first time period showed geographic clusters with high FTLBW prevalence rates in Valle de Aburrá, Nordeste, Suroeste, and Occidente subregions, while low prevalence rates were observed in Urabá, Bajo Cauca, and Magdalena Medio. The greatest FTLBW prevalence rates in Antioquia were observed in the municipalities of Rionegro, Medellín, Guarne, Angostura, Santa Rosa de Osos, Concordia, Yarumal, and Caldas, all of which had a higher FTLBW prevalence than Antioquia (between 11.9\% and $35.1 \%$ ). Chigorodó, Carepa, and Arboletes had a lower prevalence of FT-LBW compared to Antioquia. This geographical pattern was constant over the time periods for the Nordeste, Valle de Aburrá, Oriente, Suroeste, and Magdalena Medio subregions, as well as in those with the highest
FT-LBW prevalence in the last time period. The municipalities that presented a greater prevalence than Antioquia were Medellín, Rionegro, Carmen de Viboral, Yarumal, and Santa Rosa de Osos, with prevalence rates that ranged from $9.1 \%$ to $32.0 \%$. Caucasia, Segovia, Chigorodó, Mutatá, Apartadó, Zaragoza, Carepa, Necoclí, and El Bagre had a lower FT-LBW prevalence than Antioquia (figure 3).

The smoothed maps also provided evidence of a reduction in the gap between the municipalities for FT-LBW. The results of the coefficients of variation showed a decrease of $13,7 \%$ between the periods 2009-2011 and 2012-2014, indicating that intermunicipal differences are decreasing over time.

Figure 4 shows the comparisons of the prevalence maps, with the distributions of the analyzed socioeconomic indicators. We found that FT-LBW prevalence had an inverse geographical pattern to that of the socioeconomic variables, where more developed municipalities with lower poverty rates had a greater prevalence. 
The distribution of FT-LBW prevalence rates by socioeconomic conditions in the municipalities were consistent with this finding (table 3 ). For all time periods, the FT-LBW prevalence was significantly higher in the more developed and less impoverished municipalities, which provides evidence of a positive social gradient for FT-LBW.
Additionally, FT-LBW prevalence declined steadily between 2000 and 2014 for municipalities at all levels of deprivation and development (table 3). However, the most deprived and underdeveloped quintile had a significantly greater decline in FTLBW prevalence than the least deprived and under developed quintile.
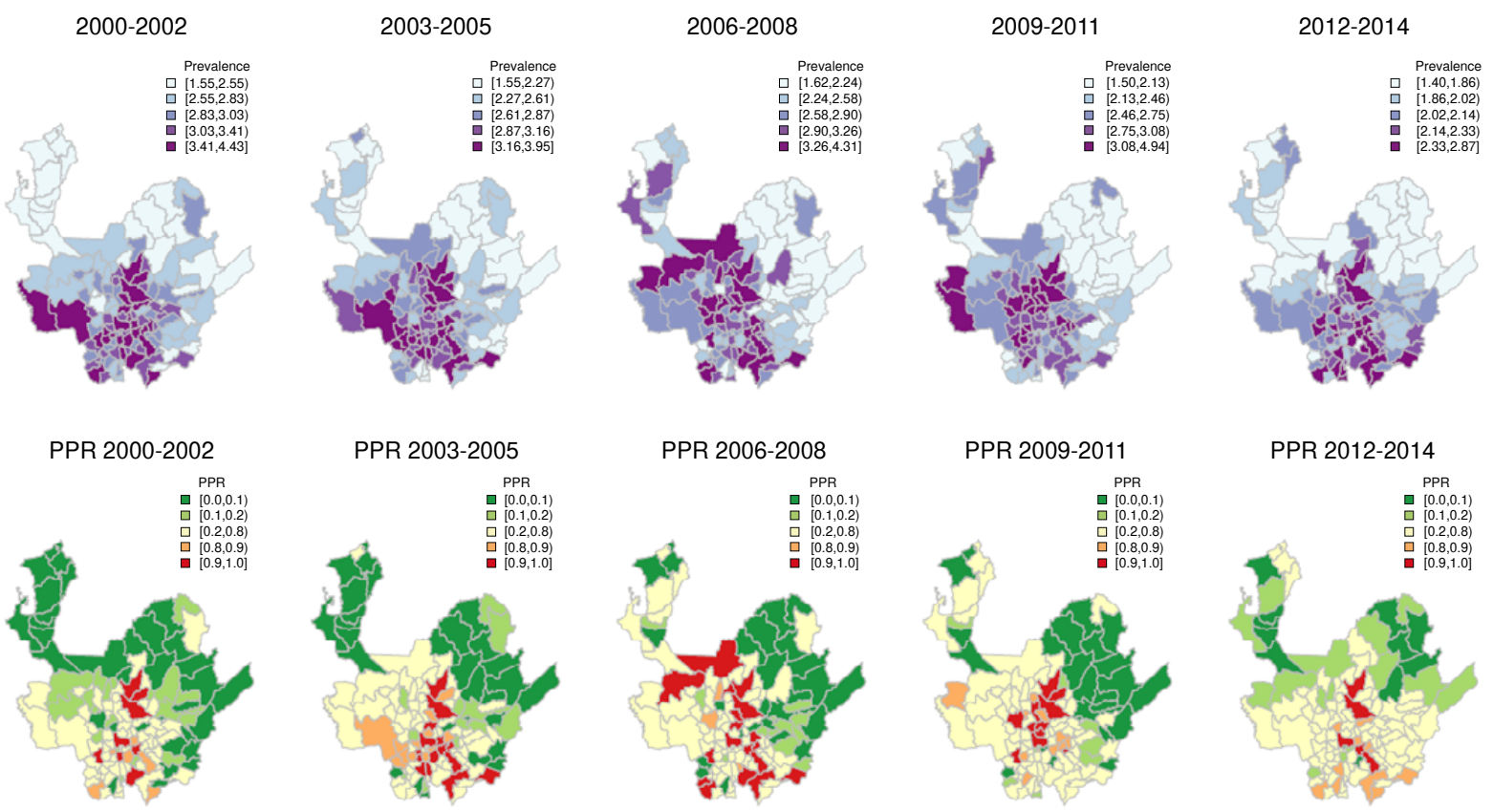

Figure 3. Spatial patterns of full-term low birth weight prevalence and posterior probability maps, Antioquia, 2000-2014
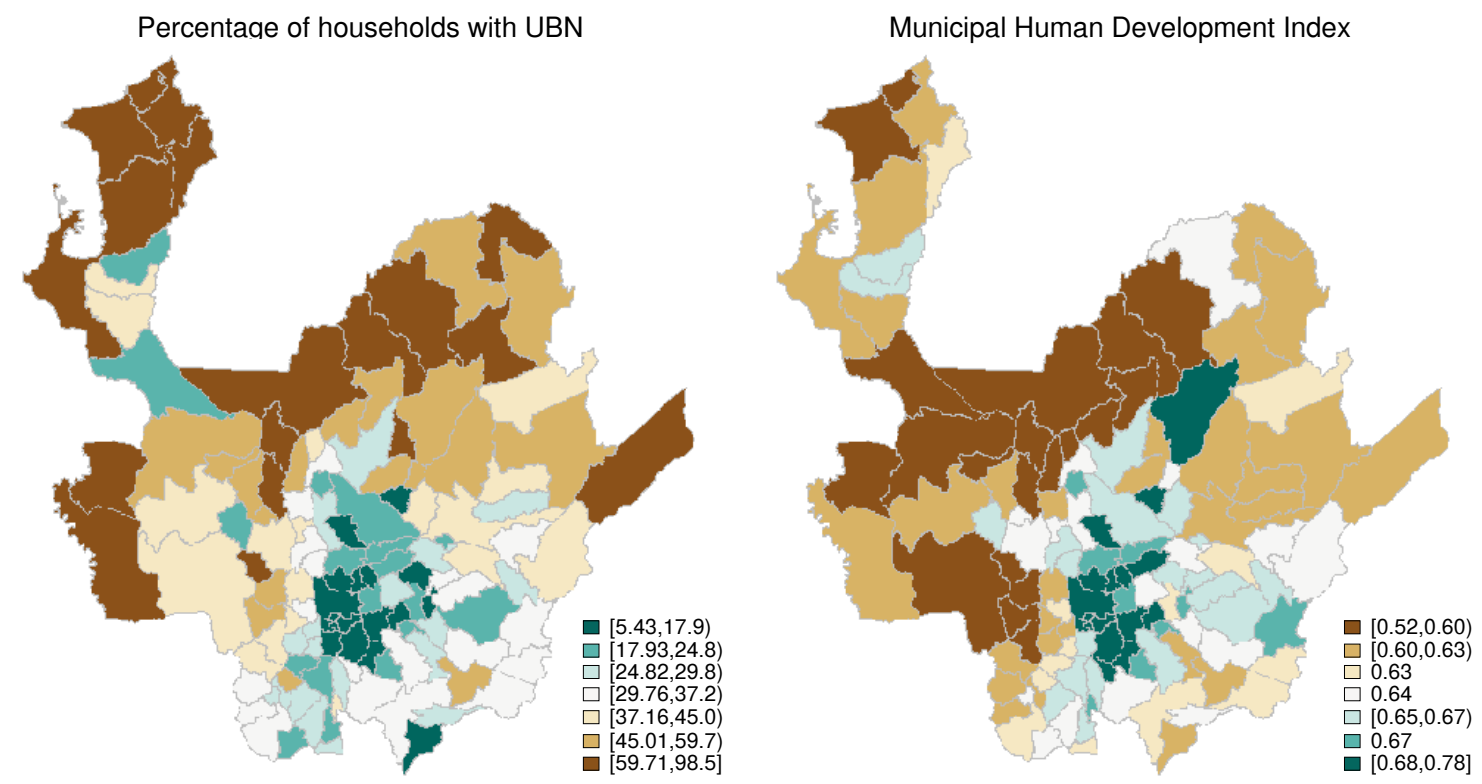

Figure 4. Spatial distributions of the percentage of households according to the Unsatisfied Basic Needs and municipal Human Development indices, Antioquia, 2005 
Table 1 shows the associations between the individual socioeconomic variables and FT-LBW. According to the results, FT-LBW was not significantly associated with the level of poverty measured by the UBN variable. For HDI, during the last two time periods, the more developed municipalities (fourth quartile) showed a significantly higher risk of FTLBW than the less developed municipalities, with an increased risk of approximately $40 \%$.

\section{Discussion}

In Antioquia and all of its subregions, FT-LBW has decreased over the last fifteen years. Recently, there has also been a reduction in geographic gaps between municipalities, although inequalities between both municipalities and subregions persist.

In this department, FT-LBW prevalence is inversely associated with the socioeconomic conditions of the municipalities, confirming a "low birth weight paradox". In other words, the greatest FT-LBW prevalence was observed in the municipalities with lower poverty rates and greater development, reflecting a positive social gradient. This socalled paradox is an incidence of low birth smaller than the expected level, according to the socioeconomic conditions of countries, ethnicities, and municipalities. This phenomenon has mainly been studied in developed countries, Asia, and Brazilian municipalities (23-26). Systematic evidence shows that mothers living in or coming from lower socioeconomic environments, with lower socioeconomic status, who have to face social disadvantages have a lower probability of delivering low birth weight babies compared to native mothers of wealthy countries or those living in developed municipalities (23-26). According to Fleuriet, the specific pathway by which this protective effect impacts birth weight has not been yet identified (26).

Here we suggest that the FT-LBW paradox may be explained more by underreporting of birth weight information in poorer municipalities than by an actual socially determined cause. Based on the findings of Silva, we also venture that factors such as improved medical interventions in preterm

Table 3. Prevalence of full-term low birth weight by quintiles of unsatisfied basic needs (UBN) and human development (HDI), Antioquia, 2000-2014

\begin{tabular}{|c|c|c|c|c|c|c|}
\hline \multirow{2}{*}{$\frac{\text { Period }}{2000-2002}$} & \multirow{3}{*}{$\begin{array}{c}\text { UBN } \\
\begin{array}{c}\text { Less poor } \\
\text { Q2 }\end{array}\end{array}$} & \multicolumn{2}{|c|}{ Prevalence (IC 95\%) } & \multirow{2}{*}{$\begin{array}{c}\text { HDI } \\
\text { Less developed }\end{array}$} & \multicolumn{2}{|c|}{ Prevalence (IC 95\%) } \\
\hline & & 3.46 & $(3.35-3.56)$ & & 2.56 & $(2.27-2.83)$ \\
\hline & & 3.24 & $(2.96-3.51)$ & Q2 & 2.76 & $(2.52-2.98)$ \\
\hline & Q3 & 3.12 & $(2.85-3.38)$ & Q3 & 2.71 & $(2.51-2.91)$ \\
\hline & Q4 & 2.51 & $(2.29-2.73)$ & Q4 & 3.14 & $(2.90-3.37)$ \\
\hline & Poorest & 2.40 & $(2.19-2.60)$ & More developed & 3.47 & $(3.36-3.57)$ \\
\hline \multirow[t]{5}{*}{ 2003-2005 } & Less poor & 3.01 & $(2.91-3.11)$ & Less developed & 2.36 & $(2.10-2.61)$ \\
\hline & Q2 & 2.97 & $(2.68-3.25)$ & Q2 & 2.19 & $(1.97-2.39)$ \\
\hline & Q3 & 2.92 & $(2.64-3.19)$ & Q3 & 2.61 & $(2.41-2.80)$ \\
\hline & Q4 & 2.29 & $(2.07-2.50)$ & Q4 & 2.88 & $(2.64-3.10)$ \\
\hline & Poorest & 2.15 & $(1.96-2.33)$ & More developed & 3.02 & $(2.91-3.12)$ \\
\hline \multirow[t]{5}{*}{$2006-2008$} & Less poor & 2.91 & $(2.80-3.00)$ & Less developed & 2.40 & $(2.15-2.65)$ \\
\hline & Q2 & 2.99 & $(2.69-3.28)$ & Q2 & 2.38 & $(2.15-2.60)$ \\
\hline & Q3 & 3.13 & $(2.82-3.42)$ & Q3 & 2.78 & $(2.58-2.98)$ \\
\hline & Q4 & 2.38 & $(2.16-2.59)$ & Q4 & 3.17 & $(2.92-3.42)$ \\
\hline & Poorest & 2.41 & (2.22-2.59) & More developed & 2.86 & $(2.76-2.96)$ \\
\hline \multirow[t]{5}{*}{ 2009-2011 } & Less poor & 2.73 & $(2.62-2.83)$ & Less developed & 2.22 & $(1.96-2.46)$ \\
\hline & Q2 & 3,22 & $(2,88-3,56)$ & Q2 & 2.06 & $(1.83-2.28)$ \\
\hline & Q3 & 2.54 & $(2.23-2.83)$ & Q3 & 2.32 & $(2.11-2.52)$ \\
\hline & Q4 & 2.11 & $(1.89-2.33)$ & Q4 & 3.18 & $(2.90-3.45)$ \\
\hline & Poorest & 2.20 & $(2.01-2.39)$ & More developed & 2.73 & $(2.62-2.83)$ \\
\hline \multirow[t]{5}{*}{ 2012-2014 } & Less poor & 2.21 & $(2.11-2.30)$ & Less developed & 1.73 & $(1.50-1.95)$ \\
\hline & Q2 & 2.31 & $(2.01-2.60)$ & Q2 & 1.75 & $(1.53-1.95)$ \\
\hline & Q3 & 2.48 & $(2.16-2.78)$ & Q3 & 1.95 & $(1.76-2.14)$ \\
\hline & Q4 & 1.67 & $(1.46-1.86)$ & Q4 & 2.36 & $(2.11-2.60)$ \\
\hline & Poorest & 1.78 & $(1.60-1.95)$ & More developed & 2.23 & $(2.13-2.32)$ \\
\hline \multirow{5}{*}{$2000-2014$} & Less poor & 2.90 & $(2.85-2.95)$ & Less developed & 2.26 & $(2.14-2.37)$ \\
\hline & Q2 & 2.98 & $(2.84-3.11)$ & Q2 & 2.25 & $(2.15-2.35)$ \\
\hline & Q3 & 2.88 & $(2.75-3.01)$ & Q3 & 2.51 & $(2.41-2.59)$ \\
\hline & Q4 & 2.22 & $(2.12-2.31)$ & Q4 & 2.97 & $(2.86-3.08)$ \\
\hline & Poorest & 2.19 & $(2.11-2.27)$ & More developed & 2.90 & $(2.85-2.95)$ \\
\hline
\end{tabular}

Q2: quintile 2; Q3, quintile 3; Q4: quintile 4 
newborns towards the end of pregnancy or artifacts in the determination of gestational age, may explain LBW rates due to the availability of better technologies that guarantee higher live births rates in more developed municipalities, even in children at high risk for low intrauterine growth caused by pregnancy complications (23).

We believe that the possible limitations of the socioeconomic indicators (UBN and HDI) used in our study have no role explaining the LBW paradox. More so, they complement each other. UBN measures vulnerability in public utilities such as water and in house conditions, while HDI measures income, school achievement, and life expectancy, and encompasses several dimensions of the determinants of social development for the health and nutrition status at the municipal level. On the other hand, no insufficient records or underreporting have been reported for those indicators.

Our findings coincide with those reported by the Colombian Instituto Nacional de Salud (INS), which reported a prevalence of FT-LBW of 3.0 cases per 100 live births in Antioquia in 2015. Although a socioeconomic analysis was not conducted, this report showed that some developed departments such as Bogotá, Boyacá, Cundinamarca, Antioquia, and Quindío, have the greatest FT-LBW rates (5).

The decrease in FT-LBW in Antioquia is similar to the trends of other countries in Latin America and worldwide but it contradicts the trends in Colombia. Donoso, et al., analyzed LBW trends in Chile and Cuba between 1991 and 2001 and they found that Chile showed increased LBW rates in 1994 but achieved stability for this indicator between 2000 and 2001 through the implementation of the complementary maternal food program and an $18 \%$ reduction in poverty between 1990 and 2000. In Cuba, a significant reduction in LBW was observed as a result of the implementation of a national program for its reduction (27-29).

There are some potential limitations of the present study. The information on municipalities' socioeconomic conditions corresponds only to data from half of the analyzed time period, which were derived from the ecological model used. Another caution to be considered is that when analyzing FT-LBW, it is very difficult to make comparisons both within and between countries because most of the information available on this phenomenon does not represent the general population. Therefore, most data do not reflect the full extent of the problem. In industrialized states, the main sources of information on LBW come from data systems and national birth records. In developing countries, $65 \%$ of newborns are not weighed, and thus, these estimates are mainly derived from data reported in national household surveys $(4,30)$. It is possible that also in Antioquia there was some level of underreporting, especially in the poorest municipalities; therefore, it is necessary to be cautious when analyzing birth weight data, as it must be complemented by continuous monitoring and control processes to reduce possible errors in calculations and comparisons.

In conclusion, FT-LBW has decreased in Antioquia and all of its subregions over the last fifteen years. There has also been a reduction in geographic gaps between municipalities, although inequalities between them and between subregions persist. FT-LBW prevalence was inversely associated with the socioeconomic conditions of the municipalities as the highest FT-LBW prevalence rates occurred in those with lower poverty rates and a greater level of development, thus reflecting a positive social gradient.

\section{Conflict of interest}

There are no conflicts of interest.

\section{Funding sources}

This research project was funded through the Convocatoria de Sostenibilidad, CODI2014-2015, of the Universidad de Antioquia.

\section{References}

1. Rojas EG, Mamani $Y$, Choque $M$ del C, Abu-khdeir MA, Bustamante D. Bajo peso al nacer y sus factores asociados en el Hospital Materno infantil Germán Urquidi. Cochabamba, Bolivia. Gaceta Médica Boliviana. 2015;38: 24-7.

2. World Health Organization, Expert Group on Prematurity. Expert Group on Prematurity: Final report. Technical Report Series No. 27. Geneva: World Health Organization; 1950.

3. Martínez R, Fernández A. Desnutrición infantil en América Latina y el Caribe. Desafíos. 2006;2:4-9.

4. Wardlaw T, Blanc A, Zupan J, Åhman E. Low birthweight: Country, regional and global estimates. The United Nations Children's Fund and World Health Organization; 2004. Accessed: October 15, 2017. Available from: https://www. unicef.org/publications/index_24840.html.

5. Ramírez P. Informe final del evento bajo peso al nacer a término, Colombia, 2015. Final Report. Bogotá: Instituto Nacional de Salud; 2014.

6. Programa de las Naciones Unidas para el Desarrollo (PNUD). Antioquia - Retos y prioridades del departamento 2016 - 2019. Medellín; 2016. Accessed: October 5, 2017. Available from: http://www.co.undp.org/content/ colombia/es/home/library/democratic_governance/retos-yprioridades-del-departamento-2016---20190.html 
7. Baños L. Factores de riesgo asociados al bajo peso al nacer. Rev Cub Salud Pública. 2012;38:238-45.

8. Coronel C, Rivera I. Peso bajo al nacer. Su influencia en la salud durante el primer año de vida. Rev Mex Pediatr. 2003;70:283-7.

9. Equipo de Vigilancia Nutricional. Protocolo de vigilancia en salud pública, bajo peso al nacer a término. Bogotá: Instituto Nacional de Salud; 2016.

10. Schempf A, Strobino D, O'Campo P. Neighborhood effects on birthweight: An exploration of psychosocial and behavioral pathways in Baltimore, 1995-1996. Soc Sci Med. 2009;68:100-10. https://doi.org/10.1016/j.socscimed. 2008.10.006

11. English PB, Kharrazi M, Davies S, Scalf R, Waller L, Neutra R. Changes in the spatial pattern of low birth weight in a southern California county: The role of individual and neighborhood level factors. Soc Sci Med. 2003;56:2073-88. https://doi.org/10.1016/S0277-9536(02)00202-2

12. Järvelin MR, Elliott $P$, Kleinschmidt I, Martuzzi M, Grundy C, Hartikainen AL, et al. Ecological and individual predictors of birthweight in a northern Finland birth cohort 1986. Paediatr Perinat Epidemiol. 1997;11:298-312. https:// doi.org/10.1111/j.1365-3016.1997.tb00007.x

13. Brooks-Gunn J, McCormick MC, Klebanov PK, McCarton C. Health care use of 3-year-old low birth weight premature children: Effects of family and neighborhood poverty. J Pediatr. 1998;132:971-5. https://doi.org/10.1016/S0022-3476 (98)70393-2

14. Coley SL, Nichols TR, Rulison KL, Aronson RE, BrownJeffy SL, Morrison SD. Does neighborhood risk explain racial disparities in low birth weight among infants born to adolescent mothers? J Pediatr Adolesc Gynecol. 2016;29: 122-9. https://doi.org/10.1016/j.jpag.2015.08.004

15. Nkansah-Amankra S, Luchok KJ, Hussey JR, Watkins $\mathbf{K}$, Liu X. Effects of maternal stress on low birth weight and preterm birth outcomes across neighborhoods of South Carolina, 2000-2003. Matern Child Health J. 2010;14:21526. https://doi.org/10.1007/s10995-009-0447-4

16. Farley TA, Mason K, Rice J, Habel JD, Scribner R, Cohen DA. The relationship between the neighbourhood environment and adverse birth outcomes. Paediatr Perinat Epidemiol. 2006;20:188-200. https://doi.org/10.1111/j.13653016.2006.00719.x

17. Masi CM, Hawkley LC, Piotrowski ZH, Pickett KE. Neighborhood economic disadvantage, violent crime, group density, and pregnancy outcomes in a diverse, urban population. Soc Sci Med. 2007;65:2440-57. https://doi. org/10.1016/j.socscimed.2007.07.014

18. Departamento Administrativo Nacional de Estadística (DANE). Proyecciones nacionales y departamentales de población 2005-2020. Bogotá: Departamento Administrativo Nacional de Estadística; 2009. Accessed: October 16, 2017. Available from:https://www.dane.gov.co/files/investigaciones/ poblacion/proyepobla06_20/7Proyecciones_poblacion.pdf
19. Barceló MA, Saez M, Cano-Serral G, Martínez-Beneito MÁ, Martínez JM, Borrell C, et al. Métodos para la suavización de indicadores de mortalidad: aplicación al análisis de desigualdades en mortalidad en ciudades del Estado español (Proyecto MEDEA). Gac Sanit. 2008;22: 596-608.

20. Besag J, York J, Mollié A. Bayesian image restoration, with two applications in spatial statistics. Ann Inst Stat Math. 1991;43:1-20. https://doi.org/10.1007/BF00116466

21. Gelman A. Prior distributions for variance parameters in hierarchical models (comment on article by Browne and Draper). Bayesian Anal. 2006;1:515-34. https://doi. org/10.1214/06-BA117A

22. Rue H, Martino S, Lindgren F, Simpson D, Riebler A, Krainski E. INLA: Functions which allow to perform full Bayesian analysis of latent Gaussian models using Integrated Nested Laplace Approximation. 2014. https:// www.researchgate.net/publication/271196512_INLA Functions_Which_Allow_to_Perform_Full_Bayesian_ Analysis_of_Latent_Gaussian_Models_Using_Integrated_ Nested_Laplace_Approximaxion

23. Silva AA, Bettiol H, Barbieri MA, Pereira MM, Brito LG, Ribeiro VS, et al. Why are the low birthweight rates in Brazil higher in richer than in poorer municipalities? Exploring the epidemiological paradox of low birthweight. Paediatr Perinat Epidemiol. 2005;19:43-9. https://doi.org/10.1111/ j.1365-3016.2004.00624.x

24. Juárez S, Ploubidis GB, Clarke L. Revisiting the "Low Birth Weight paradox" using a model-based definition. Gac Sanit. 2014;28:160-2. https://doi.org/10.1016/j.gaceta.2013. 08.001

25. Flores M, Manuck T, Simonsen SE, Dyer J, Turok D. 557: The "Latina epidemiologic paradox" in Utah: Examining risk factors for low birth weight (LBW), preterm birth (PTB), and small-for-gestational-age (SGA) in Latina and White populations. Am J Obstet Gynecol. 2009;201:S207. https:// doi.org/10.1016/j.ajog.2009.10.422

26. Fleuriet J, Sunil T. The Latina birth weight paradox: The role of subjective social status. J Racial Ethn Health Disparities. 2017. https://doi.org/10.1007/s40615-017-0419-0

27. Donoso E, Donoso A, Villarroel del PL. Mortalidad perinatal e infantil y el bajo peso al nacer en Chile y Cuba en el periodo 1991-2001. Rev Chil Obstet Ginecol. 2004;69:2038. https://doi.org/10.4067/S0717-75262004000300004

28. Programa para la Reducción del Bajo Peso al Nacer. La Habana; 1998. Accessed: October 15, 2017. Available from: http://www.sld.cu/galerias/pdf/sitios/centromed/bajo_ peso.pdf

29. Pinzón G, Vargas JE, Márquez MF, Quiroga EF. Análisis del bajo peso al nacer en Colombia 2005-2009. Rev Salud Pública. 2013;15:577-88.

30. Fondo de las Naciones Unidas para la Infancia. Progreso para la Infancia. Final Report. Report No. 6. New York: UNICEF; 2006. 